Research Article

\title{
Nutritional Quality and Safety of Complementary Foods Developed from Blends of Staple Grains and Honey Bee Larvae (Apis mellifera)
}

\author{
Shewangzaw Addisu Mekuria $\mathbb{D}^{1},{ }^{1,2}$ John N. Kinyuru, ${ }^{1}$ Beatrice Kiage Mokua, ${ }^{1}$ \\ and Mesfin Wogayehu Tenagashaw ${ }^{3}$ \\ ${ }^{1}$ Department of Food Science and Nutrition, Jomo Kenyatta University of Agriculture and Technology, P.O. Box 62000-00200, \\ Nairobi, Kenya \\ ${ }^{2}$ University of Gondar, P.O. Box 196, Gondar, Ethiopia \\ ${ }^{3}$ Department of Applied Human Nutrition, Bahir Dar University, P.O. Box 26 Bahir Dar, Ethiopia
}

Correspondence should be addressed to Shewangzaw Addisu Mekuria; shewakibr12@gmail.com

Received 30 January 2021; Revised 2 April 2021; Accepted 20 April 2021; Published 10 May 2021

Academic Editor: Giorgia Spigno

Copyright (c) 2021 Shewangzaw Addisu Mekuria et al. This is an open access article distributed under the Creative Commons Attribution License, which permits unrestricted use, distribution, and reproduction in any medium, provided the original work is properly cited.

Complementary foods must be adequate to satisfy the nutritional needs of the growing child together with breastfeeding. This study was aimed at evaluating the nutritional composition, microbial safety, and sensory quality of extruded complementary foods developed from blends of staple grains and insect bee larva (Apis mellifera). Teff, maize, soybean, and bee larva samples were milled to flour and blended before extrusion as follows: $\mathrm{ComF}_{01}$ (57\% maize, $29 \%$ teff, and $14 \%$ soybean) and $\mathrm{ComF}_{02}(58 \%$ maize, $29 \%$ teff, and 13\% bee larvae) using NutriSurvey software (version, 2007). Nutrient composition, microbial, and sensory analyses of developed flour blends were conducted using standard methods. The proximate composition of moisture, fat, fiber, carbohydrate, and energy was significantly different between the developed and commercial wean-mix foods. ComF $\mathrm{F}_{02}$ recorded the highest fat content $(14.3 \mathrm{~g} / 100 \mathrm{~g})$, energy $(427.18 \mathrm{kcal} / 100 \mathrm{~g})$, and vitamins A $(706 \mu \mathrm{g} / 100 \mathrm{~g}), \mathrm{B} 3(8.2 \mathrm{mg} / 100 \mathrm{~g})$, and B9 $(86.7 \mathrm{mg} / 100 \mathrm{~g})$ while $\mathrm{ComF}_{01}$ had the highest protein content $(12.56 \mathrm{~g} / 100 \mathrm{~g})$. Iron $(40.94 \mathrm{mg} / 100 \mathrm{~g})$ and calcium $(68.20 \mathrm{mg} / 100 \mathrm{~g})$ were the minerals with the highest content in $\mathrm{ComF}_{02}$. Both $\mathrm{ComF}_{01}$ and $\mathrm{ComF}_{02}$ met the recommended dietary allowance of nutrients for infants aged 6-12 months. Overall, the present study showed that bee larvae can be used to develop complementary foods that are nutritionally adequate, microbiologically safe, and sensory acceptable meeting the dietary allowance of infants at an acceptable level compared to conventional cereal-based foods.

\section{Introduction}

Complementary feeding is the process of providing alternative foods when breast milk alone is no longer sufficient to meet the nutritional requirements of infants, and therefore, other foods and liquids are needed, along with breast milk. Therefore, the infant transitions from exclusive breastfeeding to family foods. This period is typically from 6 to 24 months of age, even though breastfeeding may continue to two years of age and beyond [1]. This is a critical period of growth during which nutrient deficiencies and illnesses contribute globally to higher rates of undernutrition among children under five years of age [2].

While cereals are typically low in protein, cereal supplementation with local legumes that are high in protein improves the protein content of cereal-legume blends [3]. However, these plant diets are inadequate in terms of protein quality hence the need to include animal proteins [4]. Also, due to the increasing cost of animal proteins, food insecurity, population growth, and increasing need for protein-rich food [5], there should find another alternative. 
Affordable animal proteins such as edible insects are a strong source of protein with the potential for use in CFs [6, 7]. Insects are protein sources as a nutritious novel food [8]. Insect protein processing is most similar to legume protein processing [9]. The use of edible insects in CF production is not studied abundantly. Only a few studies were conducted using insects as components of CFs such as grasshoppers [7], palm weevil larvae $[10,11]$, termites $[12,13]$, crickets [10], and akokono [14] with other local foods. However, a lack of data and information on insect supply and consumption [15] and culture, taboos, customs, and ethnic preferences have highly influenced the consumption of edible insects [16]. Among insects, honey bee larvae (A. mellifera) are a highly promising food resource since honey bees are reared worldwide and eaten as a delicacy in many cultures [17]. Therefore, CFs developed from locally available and acceptable food materials are possible and, when well-formulated, are appropriate for resource-poor settings [18]. Typically, food materials will include staple cereals or starchy tubers [19].

Commercial infant food is very costly in developing countries and may be unavailable to low-income families. Hence, the production of CFs on a small industrial scale may be less costly and affordable to the majority of the population. However, this must have an "easy-to-swallow" consistency and be microbiologically safe when consumed [20]. One of the common industrial techniques for processing CFs is extrusion cooking. This method has various beneficial effects such as reduction of antinutritional factors [21, 22], starch gelatinization [23], increased soluble dietary fiber [24, 25], decreased lipid oxidation [26], and decreased microorganism contamination [27] because of increased temperature and reduced moisture in the foods during extrusion [28]. Studies by [29] reported that teff-based CFs using extrusion cooking influenced nutrient compositions of the developed CFs. Children are at risk of exposure to food-borne pathogens with the introduction of CFs. Therefore, the microbial quality of the food is one of the most important criteria in terms of consumers' requirements for CFs [28]. Thus, appropriate safe and nutrient-dense CFs [30] should be provided at an appropriate age and development for child growth. This study, therefore, was aimed at evaluating the nutritional composition, microbial safety, and sensory acceptability of complementary foods developed from blends of staple grains and insect bee larva (Apis mellifera) using the extrusion cooking method.

\section{Materials and Methods}

\subsection{Sample Collection and Preparation}

2.1.1. Sample Collection. The bee larva (A. mellifera) was aseptically collected from the University of Gondar apiary farm of modern beehives. The bees were reared in a suitable hygienic environment and fed natural pollen and nectar used for honey production. The fresh larva combs were immediately taken from the beehives and the larvae removed manually from each comb by swing and impact. Red teff (Eragrostis tef $(Z u c c$.$) ), maize (Zea mays L.), and soybean$ (Glycine max) were purchased from the Gondar city local market and Gondar Agricultural Research Center, Ethiopia.
2.1.2. Sample Preparation. The bee larvae were oven-dried at $60^{\circ} \mathrm{C}$ for $24 \mathrm{~h}$, ground to powder, and packaged in an airtight polyethylene bag until analysis [17, 31]. Teff (Eragrostis tef (Zucc. Trotter)) grains were cleaned, washed with tap water until all undesirable components were removed, and then dried by sunlight and grounded to a fine flour using a local stone mill $[29,32]$. Maize grain (Zea mays L.) was cleaned, soaked in potable water for $6 \mathrm{~h}$, drained, germinated at room temperature for $48 \mathrm{~h}$, and then sun-dried, dehulled, and milled in local mills to particle sizes ranging from $0.6 \mathrm{~mm}$ to $1.0 \mathrm{~mm}$ in diameter $[33,34]$. The soybeans (Glycine max) were cleaned, boiled (for $30 \mathrm{~min}$ ), dehulled, and dried at $60^{\circ} \mathrm{C}$ for about $13 \mathrm{~h}$, milled into flour, and sieved $(0.5 \mathrm{~mm}$ sieve) $[29,35]$. Finally, the flour samples were packed in Ziplock polyethylene bags, labeled, and stored at room temperature until the extrusion process was carried out.

2.2. Formulation of Complementary Foods. Three composite flours with two different ratios were formulated (Figure 1) using NutriSurvey software (version, 2007) according to the guidelines of complementary feeding for children aged 6-12 months [2]. The first CF $\left(\mathrm{ComF}_{01}\right)$ was composed of maize, teff, and soya bean flours in the ratio of $57: 29: 14$, respectively. Similarly, the second $\mathrm{CF}\left(\mathrm{ComF}_{02}\right)$ consisted of maize, teff, and bee larva flours in the ratio of $58: 29: 13$, respectively. Commercial (Enriched Mama's Choice) prepared infant food was bought from the market for comparison with the formulated flours.

2.3. Extrusion Processing. For ease of extrusion and best product quality, the following extrusion parameters were established for a blend formulation of composite flours, using a pilot-scale twin-screw extruder (model Clextral, BC-21 No. 124, Clextral, Firminy, France): moisture content (17\%), barrel temperature $\left(150^{\circ} \mathrm{C}\right)$, and screw speed [36] with a $29 \mathrm{~g} / \mathrm{min}$ feed rate. A die plate was used with four circular holes, each with a whole $10 \mathrm{~mm}$ diameter. The extrusion feed and water flow rates were adjusted to determine the required moisture content of the samples and were calculated by using [37]

$$
\mathrm{Wa}=\mathrm{Sw} * \frac{M-\mathrm{Mo}}{100-M},
$$

where $\mathrm{Wa}$ is the weight of water $(\mathrm{g})$, Sw is the sample flour weight ( $\mathrm{g}$ ), Mo is the original flour moisture content (\%), and $M$ is the required moisture content (\%).

The extrudates were finally dried and stored at ambient temperatures and then ground using a laboratory-scale mill (high-speed multifunctional grinder model-200) fitted with a $0.5 \mathrm{~mm}$ sieve. The flours produced from CFs were packaged in high-density polyethylene bags and stored at dry room temperature until laboratory analyses were carried out.

\subsection{Nutrient Analysis}

2.4.1. Proximate Analysis of Raw Ingredient Flours and Extruded Complementary Foods. The proximate composition of the flours from raw ingredients, the developed complementary foods, and the commercial wean mix were analyzed according to the AOAC International standard methods 


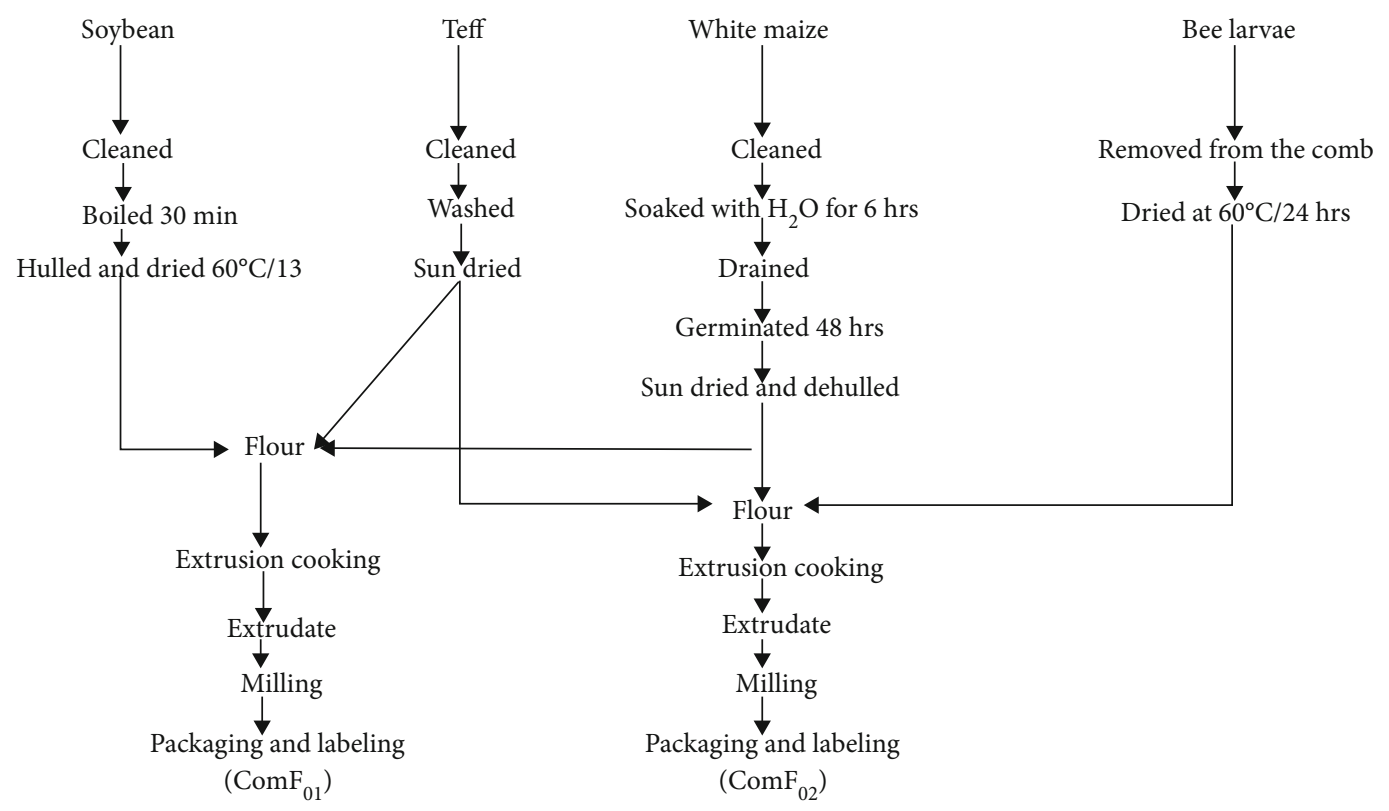

FIGURE 1: Flow chart of sample processing, formulation, and complementary food products.

[38]. Moisture content was determined by the drying method using hot-air oven circulation (method \#925.09). Ash content of a known weight sample was determined through incineration $\left(550^{\circ} \mathrm{C}\right)$ using a muffle furnace (method \#923.03). Crude protein was determined by micro-Kjeldahl (method \#979.09) and calculated by multiplying the corresponding total nitrogen content by a factor of 6.25 . The crude fat content of the sample was determined by a Soxhlet extractor (method \#930.09). Crude fiber content was determined by the following method \#962.09. Available carbohydrate was calculated by the difference while energy was calculated using Atwater's calorie conversion factors of $4 \mathrm{kcal} / \mathrm{g}$ for crude protein, $9 \mathrm{kcal} / \mathrm{g}$ for crude fat, and $4 \mathrm{kcal} / \mathrm{g}$ for available carbohydrate [39].

2.4.2. Micronutrient Analysis. The mineral content of CFs, namely, iron $(\mathrm{Fe})$, zinc $(\mathrm{Zn})$, and calcium $(\mathrm{Ca})$, was determined using a flame atomic absorption spectrometry (Shimadzu AA-6200; Shimadzu, Tokyo, Japan) according to AOAC method 985.35 [38]. The $\beta$-carotene content was determined using column chromatography and a Shimadzu $\mathrm{UV}-\mathrm{V}$ is spectrophotometer (UV-1601PC, Japan) [40]. The results were converted to vitamin A values using the conversion factor of $6 \mu \mathrm{g} \beta$-carotene: $1 \mu \mathrm{g} \mathrm{RE}$ according to [41]. Vitamin B-complex (B1, B2, B3, B6, and B9) was determined by using High-Performance Liquid Chromatography (HPLC) (Shimadzu, RID-6A) [12].

2.4.3. Antinutrient Analysis. Phytate content was determined according to [42] using the HPLC tannin, and saponin content was determined colorimetrically [43] with a UV-Vis spectrophotometer (Shimadzu model UV-1601 PC, Kyoto, Japan).

2.4.4. Contribution of Complementary Foods to Recommended Dietary Allowance (RDA). The average contri- bution of CFs to the RDA of each nutrient was calculated as a percent of the RDA [10].

$$
\% \mathrm{RDA}=\frac{\text { Amount of nutrient analyzed }}{\text { RDA for a given nutrient }} \times 100 \text {. }
$$

2.4.5. Bioavailability of Minerals. The molar ratios of phytate to zinc, calcium, and iron were calculated as the millimoles of phytate intake per day divided by the millimoles of zinc, calcium, and iron intake per day, respectively [44].

2.5. Microbial Analysis. Microbial analysis was conducted for each CF at day one, three months, and sixth months of storage and commercial wean mix. A serial dilution was done by tenfold and spread-plating techniques. A $1 \mathrm{~g}$ sample of each CFs was separately measured aseptically and dispensed separately and mixed with $10 \mathrm{ml}$ diluent saline solution. Then, the food samples were homogenized in diluent for 1 minute using a vortex shaker (Cat AC-H311 made in India). Serial dilutions were made up to $10^{10}$ dilution factors [45]. From this homogenized food sample, $1 \mathrm{ml}$ of the sample was transferred to the first cleaned and sterile test tube containing $9 \mathrm{ml}$ diluent by sterile pipette to make a serial $10^{-2}$ and $10^{-4}$ dilutions of the homogenized sample. Each of these procedures was done in triplicate for each food sample. From each dilution, $1 \mathrm{ml}$ of aliquot was transferred to a Petri dish and spread with a sterile bent glass rod on different types of solid media for the microbial count. To determine the developed foods of total plate count, Escherichia coli (E. coli), Staphylococcus, Salmonella, and Shigella spp, in the food plate count agar, eosin methylene agar, mannitol salt agar, Salmonella, and Shigella agar, respectively, were used and incubated for 24$36 \mathrm{~h}$ at $35^{\circ} \mathrm{C}[46,47]$. Yeast and molds were determined by spreading the aliquot on presolidified potato dextrose agar supplemented with $0.1 \mathrm{~g}$ chloramphenicol and incubated at 
TABLE 1: Proximate composition of individual food ingredients (g/100 g, dried weight basis).

\begin{tabular}{lcccccc}
\hline Ingredients & Moisture (\%) & Ash & Protein & Fat & Fiber & Carbohydrate \\
\hline Bee larvae & $8.68 \pm 0.17^{\mathrm{b}}$ & $3.66 \pm 0.19^{\mathrm{b}}$ & $45.70 \pm 0.85^{\mathrm{b}}$ & $24.98 \pm 0.12^{\mathrm{a}}$ & $2.74 \pm 0.10^{\mathrm{c}}$ & $14.24 \pm 0.59^{\mathrm{c}}$ \\
Soybean & $6.04 \pm 0.10^{\mathrm{c}}$ & $5.04 \pm 0.07^{\mathrm{a}}$ & $50.50 \pm 0.50^{\mathrm{a}}$ & $19.53 \pm 0.53^{\mathrm{b}}$ & $4.54 \pm 0.22^{\mathrm{a}}$ & $14.34 \pm 1.13^{\mathrm{c}}$ \\
Red teff & $8.45 \pm 0.05^{\mathrm{b}}$ & $3.44 \pm 0.04^{\mathrm{b}}$ & $9.79 \pm 0.07^{\mathrm{c}}$ & $2.65 \pm 0.06^{\mathrm{d}}$ & $3.23 \pm 0.10^{\mathrm{b}}$ & $72.44 \pm 0.06^{\mathrm{a}}$ \\
White maize & $13.36 \pm 0.21^{\mathrm{a}}$ & $0.61 \pm 0.19^{\mathrm{c}}$ & $10.10 \pm 0.13^{\mathrm{c}}$ & $4.88 \pm 0.21^{\mathrm{c}}$ & $1.50 \pm 0.06^{\mathrm{d}}$ & $69.55 \pm 0.12^{\mathrm{b}}$ \\
\hline
\end{tabular}

The results are presented as the SD of the means. Means with different superscripts (alphabets) in the same column are significantly different, $P<0.05$.

$28^{\circ} \mathrm{C}$ for 5-7 days. Results of the counted colonies were reported as $\log _{10} \mathrm{CFU/g}$ [48].

2.6. Sensory Analysis. A sensory evaluation for the acceptability of each CF gruel was done following the instructions of [2]. Gruel was made by adding $50 \mathrm{~g}$ of flour to $250 \mathrm{ml}$ of water and cooked. Sensory analysis was performed using 30 semitrained mothers selected that had an acceptable and positive attitude towards eating the products from Gondar town, Ethiopia. Orientation was given for each panelist, how to code sample products for evaluation of appearance, aroma, taste, texture/mouthfeel, and overall acceptability. The mothers were also informed to rinse their mouth with clean water before proceeding to the next food testing. A fivepoint hedonic scale ( $5=$ like very much, $4=$ like moderately, 3 = neither like nor dislike, 2 = dislike moderately, and $1=$ dislike very much) was used [35, 49].

2.7. Statistical Analysis. Results of nutritional composition, microbial, and sensory analysis of CFs were presented as means and standard deviation. One-way ANOVA and Least Significant Difference (LSD) tests were used to determine the differences among means between the CFs using SPSS for Windows Version, 23. The level of significant difference at $P<0.05$ was considered.

\section{Results and Discussion}

3.1. Nutritional Composition of Ingredients. The proximate composition of foods may be of interest in the food industry for product development, quality control, or regulatory purposes [50]. The proximate composition of individual food ingredients is presented in Table 1. Moisture content of food ingredients ranged from 6.04 to $13.36 \mathrm{~g} / 100 \mathrm{~g}$ with high moisture content being recorded for maize $(13.36 \mathrm{~g} / 100 \mathrm{~g})$. High protein $(50.50 \mathrm{~g} / 100 \mathrm{~g})$ was recorded on soybean followed by bee larvae $(45.70 \mathrm{~g} / 100 \mathrm{~g})$, maize $(9.79 \mathrm{~g} / 100 \mathrm{~g})$, and teff $(9.79 \mathrm{~g} / 100 \mathrm{~g})$. The protein content of soybean reported by $[29,51]$ was 35.59 and $27 \mathrm{~g} / 100 \mathrm{~g}$, respectively, which was lower than the present study. There were high records of carbohydrate content of teff, followed by maize, soybean, and bee larvae which were $69.55,72.44,14.34$, and $14.24 \mathrm{~g} / 100 \mathrm{~g}$, respectively.

The fat content of soybean was higher than the value reported by [29] and slightly similar to values reported by [51]. Similar findings were on protein and fat content of soaked and germinated maize grain flours reported by [52]. However, flours of teff carbohydrate content were slightly lower than the report of $[29,51]$. The variation of all these may be due to genotype, soil fertility, water availability, temperature, and environmental conditions during grain development [53] and the method of processing [54].

Results of honey bee larvae of ash, protein, and fat values of the present study were different from the reports of [31] who reported lower $35.3 \mathrm{~g} / 100 \mathrm{~g}$ protein and $14.5 \mathrm{~g} / 100 \mathrm{~g}$ fat. Moreover, $[55,56]$ reported lower ash, protein, and fat content of insect bee larvae compared to our study. The variation may be due to the species of bee insect [57], season and climate [31], and the type of insect feed [58].

3.2. Proximate Composition of CFs and Commercial Wean Mix. Extruded weaning foods were made from a combination of cereals and legumes to produce the correct protein and energy content for growing children [59]. Information about food composition is necessary for the assessment of diet quality and the development and application of foodbased dietary guidelines, providing a useful tool for the field of public health nutrition [60]. Table 2 shows the proximate $(\mathrm{g} / 100 \mathrm{~g})$ and mineral $(\mathrm{mg} / 100 \mathrm{~g})$ composition of extruded complementary foods and commercial wean mix and energy content (kcal/100 g).

Moisture, ash, protein, fat, fiber, carbohydrate, and energy (kcal) content of the developed CFs and commercial wean mix met the requirements of the Codex Alimentarius Commission [61]. Statistical analysis showed that there was a statistically significant difference $(P=0.037)$ of ash content between the foods and high records with $\mathrm{ComF}_{01}$ $(2.09 \mathrm{~g} / 100 \mathrm{~g})$. There was a significant difference $(P \leq 0.001)$ between the moisture, fat, fiber, carbohydrate, and energy content of the foods. Moisture, ash, protein, fat, fiber, carbohydrate, and energy (kcal) content of the developed CFs and commercial wean mix met the requirements of the Codex Alimentarius Commission [61].

There was a significant difference $(P \leq 0.001)$ between the moisture, fat, fiber, carbohydrate, and energy content of the foods. The moisture content of the foods ranged from 2.46 to $5.72 \mathrm{~g} / 100 \mathrm{~g}$. The $\mathrm{ComF}_{02}$ had the highest moisture content $(5.72 \mathrm{~g} / 100 \mathrm{~g})$ while the commercial wean mix had the least $(2.46 \mathrm{~g} / 100 \mathrm{~g})$. Proteins are important in both quantity and quality, for the rapid growth and development of a child. The protein content of $\mathrm{ComF}_{01}, \mathrm{ComF}_{02}$, and commercial wean mix was $12.56,11.75$, and $10.78 \mathrm{~g} / 100 \mathrm{~g}$, respectively. The significantly higher protein content in $\mathrm{ComF}_{01}$ may be due to soybean in the formulation which had higher protein content than bee larvae. However, the values of $\mathrm{ComF}_{01}$ and $\mathrm{ComF}_{02}$ were significantly higher than the commercial wean mix. There was higher fiber $(4.52 \mathrm{~g} / 100 \mathrm{~g})$ content on $\mathrm{ComF}_{01}$ followed by $\mathrm{ComF}_{02}(3.47 \mathrm{~g} / 100 \mathrm{~g})$ and commercial wean mix 
TAble 2: Proximate (g/100 g), energy content (kcal/100 g), and mineral (mg/100 g) composition of extruded complementary foods and commercial wean mix.

\begin{tabular}{|c|c|c|c|c|c|}
\hline Nutrients & $\mathrm{ComF}^{01}$ & $\mathrm{ComF}^{02}$ & Commercial wean mix & $P$ value & $\mathrm{RV}^{+}$ \\
\hline Moisture & $4.41 \pm 0.19^{\mathrm{b}}$ & $5.72 \pm 0.17^{\mathrm{a}}$ & $2.46 \pm 0.39^{c}$ & $<0.001$ & $10^{\alpha}$ \\
\hline Ash & $2.09 \pm 0.09^{\mathrm{a}}$ & $1.88 \pm 0.04^{\mathrm{b}}$ & $2.01 \pm 0.08^{\mathrm{ab}}$ & 0.037 & $<4^{\alpha}$ \\
\hline Protein & $12.56 \pm 0.17^{\mathrm{a}}$ & $11.75 \pm 0.15^{\mathrm{b}}$ & $10.78 \pm 0.29^{c}$ & $<0.01$ & $15^{+}$ \\
\hline Fat & $12.4 \pm 0.1^{\mathrm{b}}$ & $14.3 \pm 0.1^{\mathrm{a}}$ & $2.82 \pm 0.36^{\mathrm{c}}$ & $<0.001$ & $10-25^{+}$ \\
\hline Fiber & $4.52 \pm 0.04^{\mathrm{a}}$ & $3.47 \pm 0.08^{b}$ & $2.75 \pm 0.17^{\mathrm{c}}$ & $<0.001$ & $<5^{+}$ \\
\hline Carbohydrate & $64.02 \pm 0.41^{b}$ & $62.87 \pm 0.23^{\mathrm{c}}$ & $79.19 \pm 0.55^{\mathrm{a}}$ & $<0.001$ & $60-75^{\infty}$ \\
\hline Energy & $417.93 \pm 3.23^{b}$ & $427.18 \pm 2.42^{\mathrm{a}}$ & $385.25 \pm 1.77^{\mathrm{c}}$ & $<0.001$ & $400-425^{+}$ \\
\hline $\mathrm{Fe}$ & $40.17 \pm 0.38^{\mathrm{b}}$ & $40.94 \pm 0.29^{\mathrm{a}}$ & $5.79 \pm 0.16^{\mathrm{c}}$ & $<0.001$ & $9.3^{*}$ \\
\hline $\mathrm{Zn}$ & $2.84 \pm 0.18^{\mathrm{a}}$ & $2.92 \pm 0.16^{\mathrm{a}}$ & $2.32 \pm 0.11^{b}$ & 0.006 & $4.1^{*}$ \\
\hline $\mathrm{Ca}$ & $31.78 \pm 0.11^{c}$ & $44.34 \pm 0.49^{\mathrm{b}}$ & $68.20 \pm 0.12^{\mathrm{a}}$ & $<0.001$ & $0.40^{*}$ \\
\hline
\end{tabular}

The results are presented as $\mathrm{SD}$ of the means. $\mathrm{ComF}^{01}$ : complementary food 01 (white maize+red teff+soybean); $\mathrm{ComF}^{02}$ : complementary food 02 (white maize+red teff+insect bee larvae); RV: recommended value; commercial wean mix (Enriched Mama's Choice); means with different superscripts (alphabets) in the same row are significantly different $(P<0.05) ;{ }^{*}$ sources: $[62,63] ;{ }^{+}$source [32]; ${ }^{\alpha}[64] ;{ }^{\infty}$ estimated from data given for protein and fat in the codex standard.

TABLE 3: Vitamin composition of complementary foods and commercial wean mix per $100 \mathrm{~g}$.

\begin{tabular}{|c|c|c|c|c|c|}
\hline Vitamins & $\mathrm{ComF}_{01}$ & $\mathrm{ComF}_{02}$ & Commercial wean mix & $P$ value & $\mathrm{RV}^{\alpha}$ \\
\hline$\overline{\text { Vitamin } \mathrm{A}(\mu \mathrm{g})}$ & $167.3 \pm 5.84^{\mathrm{c}}$ & $706.8 \pm 16.28^{\mathrm{b}}$ & $2082.02 \pm 85.08^{\mathrm{a}}$ & $<0.001$ & 400 \\
\hline $\mathrm{B} 1$ (thiamine) (mg) & $0.81 \pm 0.09^{\mathrm{a}}$ & $0.48 \pm 0.06^{\mathrm{b}}$ & $0.24 \pm 0.36^{\mathrm{c}}$ & $<0.001$ & 0.36 \\
\hline B2 (riboflavin) (mg) & $0.70 \pm 0.07^{\mathrm{a}}$ & $0.26 \pm 0.03^{c}$ & $0.44 \pm 0.20^{\mathrm{b}}$ & $<0.001$ & 0.36 \\
\hline B3 (niacin) (mg) & $5.23 \pm 0.41^{\mathrm{bc}}$ & $8.20 \pm 0.32^{\mathrm{a}}$ & $6.33 \pm 1.43^{\mathrm{c}}$ & $<0.001$ & 6.0 \\
\hline B6 (pyridoxine) (mg) & $0.29 \pm 0.019^{c}$ & $0.45 \pm 0.01^{\mathrm{ab}}$ & $0.53 \pm 0.47^{\mathrm{a}}$ & $<0.001$ & 0.44 \\
\hline B9 (folate) $(\mu \mathrm{g})$ & $51.0 \pm 4.9^{c}$ & $86.70 \pm 1.80^{\mathrm{a}}$ & $77.76 \pm 16.31^{\mathrm{ab}}$ & $<0.001$ & 83 \\
\hline
\end{tabular}

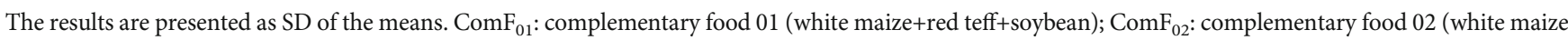
+red teff+insect bee larvae); RV: recommended value; commercial wean mix (Mama's Choice); means with different superscripts (alphabets) in the same row are significantly different $P<0.05 ;{ }^{\alpha}$ sources [63].

$(2.82 \mathrm{~g} / 100 \mathrm{~g})$. The highest fat $(14.3 \mathrm{~g} / 100 \mathrm{~g})$ and energy $(427.18 \mathrm{~g} / 100 \mathrm{~g})$ content was observed in $\mathrm{ComF}_{02}$, while the least fat $(2.82 \mathrm{~g} / 100 \mathrm{~g})$ and energy $(385.25 \mathrm{~g} / 100 \mathrm{~g})$ were observed in the commercial wean mix. Nutritionally, findings of the energy content of $\mathrm{ComF}_{02}$ were higher than the $\mathrm{ComF}_{01}$ and commercial wean mix might be due to the blends of bee larva in that are high in fat.

Micronutrient deficiency is a common public health problem in developing countries, especially for infants and children in the first two years of life [65]. Iron, zinc, and calcium are important minerals in the complementary feeding of infants and young children. There was a significant difference $(P \leq 0.001)$ in mineral iron and calcium content between the developed foods and the commercial wean mix (Table 2). High values of iron $(40.94 \mathrm{mg} / 100 \mathrm{~g})$ and calcium $(68.20 \mathrm{mg} / 100 \mathrm{~g})$ were recorded in $\mathrm{ComF}_{02}$ and commercial wean mix, respectively. Mineral iron and calcium composition of both developed CFs were higher than the recommended value [62]. This might be due to the blends of insect bee larvae in complementary foods, which are rich in mineral content [31]. However, the mineral content of zinc did not fulfill the recommended value in all foods. Conversely, the commercial wean-mix zinc $(2.32 \mathrm{mg} / 100 \mathrm{~g})$ was found to be significantly lower $(P=0.006)$ than both food $\mathrm{ComF}_{01}$ and $\mathrm{ComF}_{02}$.
3.3. Vitamin Composition of CFs and Commercial Wean Mix. Establishing precise daily requirements for vitamins is not easy, and there was considerable individual variation; however, achieving the reference nutrient intake (RNI) should be possible with a healthy balanced diet [66]. The vitamin composition of the developed CFs and commercial wean mix is indicated in Table 3 . There was a significant difference $(P \leq 0.001)$ of vitamin composition between the developed CFs and commercial wean mix. Results of vitamin A showed that $\mathrm{ComF}_{02}$ and commercial wean mix fulfilled the recommended value [63]. Vitamin A content of commercial wean $\operatorname{mix}(2.08 \mathrm{mg} / 100 \mathrm{~g})$ was higher than that of $\mathrm{ComF}_{01}$ $(0.16 \mathrm{mg} / 100 \mathrm{~g})$ and $\mathrm{ComF}_{02}(0.71 \mathrm{mg} / 100 \mathrm{~g})$, respectively. Vitamin A content of $\mathrm{ComF}_{01}(0.16 \mathrm{mg} / 100 \mathrm{~g})$ did not meet the recommended value for infants and children. Vitamins thiamine $(0.81 \mathrm{mg} / 100 \mathrm{~g})$ and riboflavin $(0.70 \mathrm{mg} / 100 \mathrm{~g})$ value of ComF01 had highest values, however, low records of pyridoxine $(0.29 \mathrm{mg} / 100 \mathrm{~g})$ and folate $(51 \mu \mathrm{g} / 100 \mathrm{~g})$. Also, niacin $(8.20 \mathrm{mg} / 100 \mathrm{~g})$ and folate $(86.7 \mu \mathrm{g} / 100 \mathrm{~g})$ in $\mathrm{ComF}_{02}$ were high but could not meet the recommended value of riboflavin.

3.4. Contribution to Recommended Dietary Allowance (RDA). Table 4 summarizes the percentage contribution of macroand micronutrients provided by complementary foods and 
TABLE 4: Percentage contribution of macro- and micronutrients provided by complementary foods and commercial wean mix meeting RDA for 6-12 months.

\begin{tabular}{|c|c|c|c|c|}
\hline \multirow{2}{*}{ Nutrients } & \multirow{2}{*}{$\mathrm{RDA}$} & \multicolumn{3}{|c|}{ Percentage RDA met } \\
\hline & & ComF $_{01}$ & $\mathrm{ComF}_{02}$ & Commercial wean mix \\
\hline Energy (kcal) & 850 & 49.17 & 50.26 & 45.32 \\
\hline Protein (g/day) & 11 & 114.18 & 106.82 & 98 \\
\hline Carbohydrate (g) & 95 & 67.39 & 66.19 & 83.36 \\
\hline Fat $(\mathrm{g})$ & 30 & 41.33 & 47.67 & 9.40 \\
\hline $\mathrm{Ca}(\mathrm{mg})$ & 260 & 12.22 & 17.05 & 26.23 \\
\hline $\mathrm{Zn}$ (mg/day) & 3 & 94.67 & 97.33 & 73.33 \\
\hline $\mathrm{Fe}$ (mg/day) & 11 & 365.18 & 372.18 & 52.64 \\
\hline Vitamin A ( $\mu \mathrm{g}$ RE) & 500 & 33.34 & 141.36 & 416 \\
\hline B1 (thiamine) (mg/day) & 0.3 & 270.67 & 160 & 80 \\
\hline B2 (riboflavin) (mg/day) & 0.4 & 175 & 65 & 110 \\
\hline B3 (niacin) (mg/day) & 4.0 & 130.75 & 205 & 158.25 \\
\hline B6 (pyridoxine) (mg/day) & 0.3 & 96.67 & 150 & 176.67 \\
\hline B9 (folate) ( $\mu \mathrm{g} /$ day) & 80 & 63.75 & 108.38 & 97.2 \\
\hline
\end{tabular}

$\mathrm{ComF}_{01}$ : complementary food 01 (white maize+red teff+soybean); $\mathrm{ComF}_{02}$ : complementary food 02 (white maize+red teff+insect bee larvae); commercial wean mix (Mama's Choice); ${ }^{\beta}$ source dietary reference intake $[2,67]$.

TABle 5: Antinutrient composition of developed complementary foods $(\mathrm{mg} / 100 \mathrm{~g})$.

\begin{tabular}{lccc}
\hline \multirow{2}{*}{$\mathrm{CF}_{\mathrm{S}}$} & \multicolumn{3}{c}{ Antinutrients } \\
& Tannins & Phytates & Saponins \\
\hline $\mathrm{ComF}_{01}$ & $208.93 \pm 0.04^{\mathrm{a}}$ & $68.18 \pm 4.15^{\mathrm{a}}$ & $\mathrm{nd}$ \\
$\mathrm{ComF}_{02}$ & $119.37 \pm 0.31^{\mathrm{b}}$ & $13.13 \pm 0.63^{\mathrm{b}}$ & nd \\
Commercial wean mix & $63.69 \pm 0.34^{\mathrm{c}}$ & $10.46 \pm 0.5^{\mathrm{b}}$ & nd \\
$P$ value & $<0.001$ & $<0.001$ & - \\
\hline
\end{tabular}

The results are presented as $\mathrm{SD}$ of the means. $\mathrm{ComF}_{01}$ : complementary foods (white maize+red teff+soybean); $\mathrm{ComF}_{02}$ : complementary foods (white maize+red teff+insect bee larvae); nd: not detected.

commercial wean mix which met RDA for 6-12 months. The contribution of $\mathrm{ComF}_{01}, \mathrm{ComF}_{02}$, and commercial wean mix to the RDA of protein was the highest which was 114.18, 106.82, and $98 \%$, respectively; however, with the exception of the energy contribution from $\mathrm{ComFs}_{02}$, the contribution of the two CFs to the RDA of energy for infants was less than $50 \%$. All foods had the potential to contribute to the RDA of iron (52.64-365.18\%) and zinc (73.33-97.33\%); however, the contribution of calcium (12.22-26.23\%) intake was very low. The vitamins' potential contribution of CFs to the RDA were highest except $\mathrm{ComF}_{01}$ for vitamin $\mathrm{A}$ (33.34\%).

3.5. Antinutrient Composition of CFs. Antinutrients in complementary foods for children could have a negative impact on nutritional status [68]. Therefore, using extrusion significantly reduced the antinutritional factors of the formulated diets [22]. Antinutrient composition of developed CFs in $\mathrm{mg} / 100 \mathrm{~g}$ is shown in Table 5 .

Antinutritional (mg/100 g) content showed high records of tannins (208.93) and phytates (68.18) in $\mathrm{ComF}_{01}$ than in $\mathrm{ComF}_{02}$ and commercial wean mix which showed tannins of 119.37 and 63.60 and phytates of 13.13 and 10.46, respectively. However, saponins were not detected in both CFs and commercial wean mix. Cereal-based complementary foods are high in phytates which limit the bioavailability of nutrients, including iron, calcium, zinc, and, in some cases, proteins, which are crucial to the development of infants [69]. Tannin-protein complexes can contribute to digestive enzyme inactivation and decrease the digestibility of proteins by protein substrate association with ionizable iron [70]. The existence of tannins in food could reduce the quality of foods, suppress growth, reduce iron absorption, harm the gastrointestinal tract's mucosal lining, altercation excretion, and increase protein and critical amino acid excretion [22].

3.6. Bioavailability of Minerals. The calculated results of both CF concentration of phytate and its molar ratio of minerals calcium, iron, and zinc were in line with the recommended limits (Table 6).

The recommended limits of phytate to calcium, iron, and zinc were (phytate to calcium) $<0.24$ for calcium [74], ( phytate to iron) $<1$ for iron [71], and (phytate to zinc) $<15$ for zinc [72]. (0.14, 0.03, and 0.02), calcium (2.40, 0.45, and $0.45)$, and zinc $(0.13,0.02$, and 0.01$)$, respectively, showed good iron, zinc, and calcium bioavailability in both developed complementary foods and commercial wean mix. This might be due to the low amounts of phytate in the CFs. Also, the addition of legumes $\left(\mathrm{ComF}_{01}\right)$ can slightly improve the iron content of those diets; however, the bioavailability of this nonheme iron source was lower than hemi iron [41]. According to the report of [75], lowering the phytic acid should enhance the bioavailability of iron and zinc in the extrudates as phytic acid has been implicated in making these minerals unavailable. Extrusion cooking results in the degradation of cereals and legumes' antinutrients by about 30\% [76]. The inhibitory effect of phytate on bioavailability increases with 
TABLE 6: Minerals : phytate molar ratio in developed complementary foods and commercial wean mix.

\begin{tabular}{lccc}
\hline Sample & Phytate: iron & Phytate: zinc & Phytate: calcium \\
\hline ComF $_{01}$ & 0.14 & 2.40 & 0.13 \\
ComF $_{02}$ & 0.03 & 0.50 & 0.02 \\
Commercial wean mix & 0.02 & 0.45 & 0.01 \\
Limits & $<1^{\alpha}$ & $<15^{\beta}$ & $<0.24^{*}$ \\
\hline
\end{tabular}

$\mathrm{ComF}_{01}$ : complementary foods 01 (white maize+red teff+soybean); $\mathrm{ComF}_{02}$ : complementary foods 02 (white maize+red teff+insect bee larvae); commercial wean mix (Mama's Choice); ${ }^{\alpha}$ sources: [71]; ${ }^{\beta}$ source: [72]; ${ }^{[}[73]$.

TABLE 7: Microbiological counts $\left(\log _{10} \mathrm{CFU} / \mathrm{g}\right)$ of the developed complementary foods after three and six months of storage and commercial wean mix.

\begin{tabular}{|c|c|c|c|c|c|c|}
\hline \multirow{2}{*}{ Microorganisms } & \multicolumn{2}{|c|}{ At 3 months } & \multicolumn{2}{|c|}{ At 6 months } & \multirow{2}{*}{ Commercial wean mix } & \multirow{2}{*}{ Limit $^{*}$} \\
\hline & ComF $_{01}$ & $\mathrm{ComF}_{02}$ & $\mathrm{ComF}_{01}$ & $\mathrm{ComF}_{02}$ & & \\
\hline E. coli & nd & nd & nd & nd & nd & $<1$ \\
\hline S. aureus & nd & nd & nd & nd & nd & $<1$ \\
\hline Salmonella & nd & nd & nd & nd & nd & $0 / 25 \mathrm{~g}$ \\
\hline Shigella & nd & nd & nd & nd & nd & $0 / 25 \mathrm{~g}$ \\
\hline Total plate count & 3.36 & 3.04 & 3.46 & 3.17 & Nil & $<5$ \\
\hline Yeast & 2.00 & 2.00 & 2.30 & 2.18 & Nil & $<3$ \\
\hline Molds & 2.17 & 2.30 & 2.60 & 2.40 & Nil & $<3$ \\
\hline
\end{tabular}

Results are presented as means. CFU: colony forming units; nd: not detected; ${ }^{*}[64,79]$.

the increment of phytate intake [77]. In the gastrointestinal tract, phytic acid binds trace elements and macro elements such as copper, calcium, magnesium, and iron to make dietary minerals inaccessible for consumption and used by the body [78].

3.7. Microbiological Loads of CFs. The microbial load of any food material is, however, a useful index of quality of the extrudate as well as revealing the potential safety status of the extruded food products from a human consumption point of view and storage of the products [45]. Table 7 summarizes the microbiological counts $\left(\log _{10} \mathrm{CFU} / \mathrm{g}\right)$ of the developed CFs at day one and after storage of three months and six months and commercial wean mix.

The microbial results of both CFs were below the acceptable level, i.e., acceptable limit $\left(<5 \log _{10} \mathrm{CFU} / \mathrm{g}\right)$ [64] and not detected on commercial wean mix. High levels of moisture (above 10\%) exacerbate spoilage by encouraging microbial activity and chemical reactions that reduce the shelf life of the food [80]. Therefore, microbial counts of E. coli, Staphylococcus, Salmonella, and Shigella spp, total plate count, yeast, and mold of both CFs were within safe levels. This may be due to the quality control measures used during manufacturing and techniques $[81,82]$ as well as because of low moisture content [83].

On day one, microbial counts of both CFs were not detected. Similarly, at six months of storage, there were no E. coli, Staphylococcus, Salmonella, and Shigella spp detected. The findings of bacterial Shigella, Salmonella, and Staphylococcus spp of the present study were in line with the study of [84], which were not detected from the developed weaning food samples. This was likely since these were not persistent in the environment or were more likely destroyed during cooking $[85,86]$.
There was a slight increment of microbial load at three and six months of storage. The mean total plate count of $\mathrm{ComF}_{01}\left(3.36 \log _{10} \mathrm{CFU} / \mathrm{g}\right)$ and $\mathrm{ComF}_{02}\left(3.04 \log _{10} \mathrm{CFU} / \mathrm{g}\right)$ were recorded at three months and $\mathrm{ComF}_{01}\left(3.46 \log _{10}\right.$ $\mathrm{CFU} / \mathrm{g})$ and $\mathrm{ComF}_{01}\left(3.17 \log _{10} \mathrm{CFU} / \mathrm{g}\right)$ at six months of storage. The detection of total plate counts in the CFs at an acceptable level could be due to cross-contamination through the migration of substances from the packaging into food [87] or storage time increased [45] or contamination of packaging material [88-90].

Yeast counts of $\mathrm{ComF}_{01}$ at three $\left(2.0 \log _{10} \mathrm{CFU} / \mathrm{g}\right)$ and six $\left(2.30 \log _{10} \mathrm{CFU} / \mathrm{g}\right)$ months of storage were as mean mold counts at three $\left(2.17 \log _{10} \mathrm{CFU} / \mathrm{g}\right)$ and six $\left(2.60 \log _{10} \mathrm{CFU} / \mathrm{g}\right)$ months of storage were recorded. Yeast counts of $\mathrm{ComF}_{02}$ at three $\left(2.00 \log _{10} \mathrm{CFU} / \mathrm{g}\right)$ and six months $\left(2.18 \log _{10} \mathrm{CFU} / \mathrm{g}\right)$ and mold at three $\left(2.30 \log _{10} \mathrm{CFU} / \mathrm{g}\right)$ and six months (2.40 $\log _{10} \mathrm{CFU} / \mathrm{g}$ ) were recorded. The presence of molds and yeast development in the developed CFs after three and six months of storage might be due to packaging or storage conditions. Most yeasts and molds were obligatorily aerobic, and their temperature range $\left(10-35^{\circ} \mathrm{C}\right)$ was also broad [91]. Comparing yeast and molds, higher mold counts (CFU/g) of the developed $\mathrm{CF}$ s were recorded than yeast in both $\mathrm{CF}_{\mathrm{S}}$ but not detected on commercial wean mix. This may be due to molds' moisture requirements being relatively low, although yeasts generally require higher water activity [92]. Therefore, suppression of microbial growth appears to be favored under high temperature and low moisture environments [93].

3.8. Sensory Analysis. The sensory analysis relies on consumers to provide the data on which decisions were based [94]. Sensory attributes and overall acceptance of commercial wean mix (Table 8) were higher than those of $\mathrm{ComF}_{01}$ and 
TABLE 8: Sensory analysis of the developed complementary foods compared to commercial wean mix.

\begin{tabular}{|c|c|c|c|c|}
\hline Characteristic & $\mathrm{ComF}_{01}$ & $\mathrm{ComF}_{02}$ & Commercial wean mix & $P$ value \\
\hline Appearance & $3.77 \pm 0.82^{\mathrm{c}}$ & $4.07 \pm 0.69^{\mathrm{bc}}$ & $4.41 \pm 0.74^{\mathrm{a}}$ & 0.003 \\
\hline Aroma & $3.73 \pm 0.91^{\mathrm{c}}$ & $4.23 \pm 0.63^{\mathrm{ab}}$ & $4.40 \pm 0.80^{\mathrm{a}}$ & 0.003 \\
\hline Taste & $3.57 \pm 0.73^{\mathrm{c}}$ & $4.43 \pm 0.63^{\mathrm{ab}}$ & $4.50 \pm 0.68^{\mathrm{a}}$ & $<0.001$ \\
\hline Texture/mouth feel & $3.77 \pm 0.71^{\mathrm{c}}$ & $3.97 \pm 0.61^{b c}$ & $4.47 \pm 0.51^{\mathrm{a}}$ & $<0.001$ \\
\hline Overall acceptability & $3.63 \pm 0.61^{c}$ & $4.20 \pm 0.55^{\mathrm{b}}$ & $4.63 \pm 0.49^{\mathrm{a}}$ & $<0.001$ \\
\hline
\end{tabular}

The results are presented as $\mathrm{SD}$ of the means. $\mathrm{ComF}_{01}$ : complementary foods 01 (white maize+red teff+soybean); ComF $\mathrm{F}_{02}$ : complementary foods 02 (white maize+red teff+insect bee larvae); commercial wean mix (Mama's Choice); means with different superscripts (alphabets) in the same row are significantly different $(P<0.05)$.

$\mathrm{ComF}_{02}$. The small number of participants used in the sensory test increased the chance of getting accurate and reliable results [95]. There was a statistically significant difference $(P=0.003)$ in appearance and aroma between the developed $\mathrm{CFs}$ and commercial wean mix. The appearance was an important attribute in food choice and acceptance [96]. The outcome of the sensory evaluation indicated that $\mathrm{ComF}_{01}$ and $\mathrm{ComF}_{02}$ samples were similar in appearance while the commercial wean mix differed significantly. However, $\mathrm{ComF}_{01}$ had a lower score of overall acceptance than $\mathrm{ComF}_{02}$. This may be due to the higher presence of tannins in $\mathrm{ComF}_{01}$. According to the report of [75], tannins also decrease palatability. There was a highly significant difference $(P \leq 0.001)$ between the foods with regard to taste, texture, and overall acceptability. The aroma, taste, and overall acceptability of $\mathrm{ComF}_{02}$ were liked more by the panelists as compared to those of $\mathrm{ComF}_{01}$ but were of lower acceptability than those of the commercial wean mix. The best score rating of the commercial wean mix would be as a result of flavoring additions in the product [97].

Infants and toddlers present a challenge to sensory and consumer researchers because of their inability to communicate verbally, limited cognitive abilities, and very low attention span [98]. Besides, most found young children to have lower sensitivity than adults [99]. Sensory testing with infants and young children, therefore, has often employed indirect approaches. Therefore, the sensory evaluation of the present study was conducted by mothers or caretakers. For preference evaluation, parents' liking is important in deciding if a given CF would be suitable for their infants [100, 101]. All sensory evaluations of the developed CFs and commercial wean mix were above the minimum threshold i.e., the hedonic scale which was equal to three, neither likes nor dislikes [10].

\section{Conclusions}

The present study revealed that the development of CFs using extrusion cooking makes the products desirable in nutritional quality, microbial safety, and sensory acceptability. The nutritional composition of the developed foods meets the Codex Alimentarius Standard of the recommended dietary allowance for infants. The potential of using bee larvae as a novel ingredient in the development of CFs has been an alternative protein gained from plant-based protein sources. Using bee larvae with staple grains as a component of CFs is appropriate for macro- and micronutrient improvement of CF development for infants and young children. The extruded complementary foods containing bee larvae can be microbially safe and acceptable similar to cereal-based complementary foods and have the potential to contribute to the recommended dietary allowance. However, further study should be done on the effects of the developed CF foods on biochemical, hematological, and histopathological changes using laboratory animals.

\section{Data Availability}

The data used and/or analyzed in the study are available from the corresponding author on reasonable request.

\section{Conflicts of Interest}

The authors declare that there is no conflict of interest regarding the publication of this paper.

\section{Acknowledgments}

The authors would like to give special thanks to the German Academic Exchange Service (DAAD) for the sponsorship of this research work. We are also grateful to Jomo Kenyatta University of Agriculture and Technology, Kenya; Holeta Agricultural Center; Bahir Dar University; and University of Gondar, Ethiopia, for this research laboratory work. This research was funded by DAAD/RUFORUM, In-Country/In-Region Scholarship Programme-Regional Universities Forum for Capacity Building in Agriculture 2018, Germany, grant number (57429563).

\section{References}

[1] WHO, Appropriate complementary feeding, 2019.

[2] WFP, Nutritional guidance for complementary food, 2018, https://docs.wfp.org/api/documents/WFP-0000102245/ download/.

[3] M. Abdulkadir and J. B. Danjuma, "Microbial profile and nutritional quality during the fermentation of cereal based weaning food fortified with soya bean and tiger nut using starter culture," World Scientific News, vol. 24, pp. 103-115, 2015.

[4] M. Henchion, M. Hayes, A. M. Mullen, M. Fenelon, and B. Tiwari, "Future protein supply and demand: strategies 
and factors influencing a sustainable equilibrium," Food, vol. 6 , no. 7 , p. 53, 2017.

[5] B. Tiencheu and H. Womeni, "Entomophagy: insects as food," in Shields, VDC Entomophagy: Insects as Food, pp. 233-253, IntechOpen, 2017.

[6] A. Adámková, J. Mlček, L. Kouřimská et al., "Nutritional potential of selected insect species reared on the island of Sumatra," International Journal of Environmental Research and Public Health, vol. 14, no. 5, p. 521, 2017.

[7] M. Mmari, J. N. Kinyuru, H. S. Laswai, and J. Okoth, "Application of edible insects in enriching complementary foods made from common plant sources," in Paper presented at the Fifth African Higher Education Week and RUFORUM Biennial Conference 2016, "Linking Agricultural Universities with Civil Society, the Private Sector, Governments and Other Stakeholders in Support of Agricultural Development in Africa", Cape Town, South Africa, 2016http://repository .ruforum.org/.

[8] J. N. Kinyuru, S. O. Konyole, S. A. Onyango-Omolo et al., "Nutrients, functional properties, storage stability and costing of complementary foods enriched with either termites and fish or commercial micronutrients," Journal of Insects as Food and Feed, vol. 1, no. 2, pp. 149-158, 2015.

[9] A. Gravel and A. Doyen, "The use of edible insect proteins in food: challenges and issues related to their functional properties," Innovative Food Science \& Emerging Technologies, vol. 59, p. 102272, 2020.

[10] I. Agbemafle, D. Hadzi, F. K. Amagloh, F. B. Zotor, and M. B. J. F. Reddy, "Nutritional, microbial, and sensory evaluation of complementary foods made from blends of orange-fleshed sweet potato and edible insects," Foods, vol. 9, no. 9, p. 1225, 2020.

[11] J. Ayensu, C. Larbie, R. A. Annan et al., "Palm weevil larvae (Rhynchophorus phoenicis Fabricius) and orange-fleshed sweet potato-enriched biscuits improved nutritional status in female Wistar albino rats," Journal of Nutrition, vol. 2020, pp. 1-8, 2020.

[12] O. T. Adepoju and K. Ajayi, "Nutrient composition and adequacy of two locally formulated winged termite (Macrotermes bellicosus) enriched complementary foods," Journal of Food Research, vol. 5, no. 4, pp. 79-89, 2016.

[13] J. N. Kinyuru, J. B. Mogendi, C. A. Riwa, and N. W. Ndung'u, "Edible insects-a novel source of essential nutrients for human diet: learning from traditional knowledge," Animal Frontiers, vol. 5, no. 2, pp. 14-19, 2015.

[14] M. E. Parker, S. Zobrist, H. E. Lutterodt et al., "Evaluating the nutritional content of an insect-fortified food for the child complementary diet in Ghana," BMC nutrition, vol. 6, no. 1, pp. 1-11, 2020.

[15] N. Roos, "Insects and human nutrition," in Edible insects in sustainable food systems, pp. 83-91, Springer, 2018.

[16] J. N. Kinyuru, D. Nyangena, E. Kamau et al., "The role of edible insects in diets and nutrition in East Africa," in Edible insects in sustainable food systems, pp. 93-108, Springer, 2018.

[17] A. B. Jensen, J. Evans, A. Jonas-Levi et al., "Standard methods for Apis mellifera brood as human food," Journal of Apicultural Research, vol. 58, no. 2, pp. 1-28, 2019.

[18] S. O. Konyole, J. N. Kinyuru, B. O. Owuor et al., "Acceptability of amaranth grain-based nutritious complementary foods with dagaa fish (Rastrineobola argentea) and edible termites
(Macrotermes subhylanus) compared to corn soy blend plus among young children/mothers dyads in Western Kenya," Journal of Food Research, vol. 1, no. 3, pp. 111-120, 2012.

[19] M. J. R. Nout, "Processed weaning foods for tropical climates," International Journal of Food Sciences and Nutrition, vol. 43, no. 4, pp. 213-221, 1993.

[20] UNICEF, "Improving young children's diets during the complementary feeding period," in UNICEF Programming Guidance, p. 76, UNICEF, New York, 2020.

[21] N. Nikmaram, S. Y. Leong, M. Koubaa et al., "Effect of extrusion on the anti-nutritional factors of food products: an overview," Food Control, vol. 79, pp. 62-73, 2017.

[22] M. O. Omosebi, O. F. Osundahunsi, and T. N. Fagbemi, "Effect of extrusion on protein quality, antinutritional factors, and digestibility of complementary diet from quality protein maize and soybean protein concentrate," Journal of Food Biochemistry, vol. 42, no. 4, article e12508, 2018.

[23] P. Wang, Y. Fu, L. Wang, A. S. Saleh, H. Cao, and Z. Xiao, "Effect of enrichment with stabilized rice bran and extrusion process on gelatinization and retrogradation properties of rice starch," Starch-Stärke, vol. 69, no. 7-8, p. 1600201, 2017.

[24] S. Rashid, A. Rakha, F. M. Anjum, W. Ahmed, and M. Sohail, "Effects of extrusion cooking on the dietary fibre content and water solubility index of wheat bran extrudates," International journal of food science technology, vol. 50, no. 7, pp. 1533-1537, 2015.

[25] L. Zhong, Z. Fang, M. L. Wahlqvist, J. M. Hodgson, and S. K. Johnson, "Extrusion cooking increases soluble dietary fibre of lupin seed coat," LWT, vol. 99, pp. 547-554, 2019.

[26] W. E. Artz and S. K. Rao, "Lipid oxidation in extruded products," in Thermally Generated Flavors, vol. 543, pp. 296-314, American Chemical Society, 1993.

[27] L. Almendares Calderón, V. A. García Mena, and J. M. Román Miranda, "Development of an extruded food product similar to fried potatoes, based on by-products of potatoes and rice. Physicochemical and microbiological evaluation," Food Science and Technology, vol. 41, pp. 359-364, 2021.

[28] G. Baskar and R. Aiswarya, "Role of extrusion technology in food processing and its effect on nutritional values," International Journal of Modern Science and Technology, vol. 1, no. 1, pp. 1-4, 2016.

[29] M. W. Tenagashaw, G. M. Kenji, E. T. Melaku, S. HuyskensKeil, and J. N. Kinyuru, "Teff-based complementary foods fortified with soybean and orange-fleshed sweet potato," Journal of Food Research, vol. 6, no. 1, pp. 112-122, 2016.

[30] WHO, Infant and Young Child Feeding: Model Chapter for Textbooks for Medical Students and Allied Health Professionals, World Health Organization, 2009.

[31] S. Ghosh, C. Jung, and V. B. Meyer-Rochow, "Nutritional value and chemical composition of larvae, pupae, and adults of worker honey bee, Apis mellifera ligustica as a sustainable food source," Journal of Asia-Pacific Entomology, vol. 19, no. 2, pp. 487-495, 2016.

[32] A. Codex, "Guidelines on formulated complementary foods for older infants and young children. Amended document 1991," Report No.: CAC/GL (pp. 8-1991), 2017.

[33] Y. Abebe, B. J. Stoecker, M. J. Hinds, and G. E. Gates, "Nutritive value and sensory acceptability of corn-and kocho-based foods supplemented with legumes for infant feeding in southern Ethiopia," African Journal of Food, Agriculture, Nutrition and Development, vol. 6, no. 1, pp. 1-19, 2006. 
[34] Z. Tona, B. Tafese, and B. Tefera, "Blending germinated maize, pumpkin pulp and its seed improves zinc and vitamin A without compromising nutritive value and sensory attributes of local complementary food porridge," Food and Public Health, vol. 5, no. 4, pp. 103-107, 2015.

[35] S. F. Forsido, H. T. Duguma, T. B. Lema, B. Sturm, and O. Hensel, "Nutritional and sensory quality of composite extruded complementary food," The American Journal of Clinical Nutrition, vol. 7, no. 2, pp. 882-889, 2019.

[36] P. Maruvada, J. W. Lampe, D. S. Wishart et al., "Perspective: dietary biomarkers of intake and exposure-exploration with omics approaches," Journal of Food Biochemistry, vol. 11, no. 2, pp. 200-215, 2019.

[37] P. Golob, G. Farrell, and J. E. Orchard, Crop Post-Harvest: Science and Technology, Wiley Online Library, 2002.

[38] AOAC, Official Methods of Analysis of AOAC International, AOAC international, Gaithersburg, Md, 18th edition, 2005.

[39] FAO, Food Energy: Methods of Analysis and Conversion Factors: Report of a Technical Workshop, Fao, Rome, 2003.

[40] A. Biswas, J. Sahoo, and M. Chatli, "A simple UV-Vis spectrophotometric method for determination of $\beta$-carotene content in raw carrot, sweet potato and supplemented chicken meat nuggets," LWT - Food Science and Technology, vol. 44, no. 8, pp. 1809-1813, 2011.

[41] WHO/FAO, Vitamin and Mineral Requirements in Human Nutrition, vol. 2, National Academy Press, Washington, DC, 2004.

[42] A. Camire and F. Clydesdale, "Analysis of phytic acid in foods by HPLC,” Food Science, vol. 47, no. 2, pp. 575-578, 1982.

[43] V. L. Singleton and J. A. Rossi, "Colorimetry of total phenolics with phosphomolybdic-phosphotungstic acid reagents," American journal of Enology and Viticulture, vol. 16, no. 3, pp. 144-158, 1965.

[44] V. Castro-Alba, C. E. Lazarte, B. Bergenståhl, and Y. Granfeldt, "Phytate, iron, zinc, and calcium content of common Bolivian foods and their estimated mineral bioavailability," Food Science and Nutrition, vol. 7, no. 9, pp. 28542865, 2019.

[45] O. Oluwole, S. Awonorin, F. Henshaw, G. Elemo, and O. Ebuehi, "Assessment of microbial changes and nutritional qualities of extruded white yam (Dioscorea rotundata) and bambara groundnut (Vigna subterranean) blends," Food and Nutrition Sciences, vol. 4, no. 1, pp. 100-107, 2013.

[46] K. Anigo, D. Ameh, S. Ibrahim, and S. Danbauchi, "Nutrient composition of complementary food gruels formulated from malted cereals, soybeans and groundnut for use in NorthWestern Nigeria," African Journal of Food Science, vol. 4, no. 3, pp. 65-72, 2010.

[47] G. Getachew, "Microbiological quality of traditional and commercial weaning foods in Jimma town Southwestern Ethiopia," Food Science and Quality Management, vol. 63, 2017.

[48] J. F. Spencer and A. L. R. de Spencer, "Food microbiology protocols," Springer Science \& Business Media, vol. 14, 2001.

[49] M. C. Meilgaard, B. T. Carr, and G. V. Civille, Sensory Evaluation Techniques, CRC press, 2006.

[50] S. S. Nielsen, "Proximate assays in food analysis," Progress in Drug Research, vol. 71, pp. 21-31, 2006.

[51] H. Menure, "Effect of grain teff, sorghum and soybean blending ratio and processing condition on weaning food quality," Journal of Food Processing and Technology, vol. 8, no. 3, 2017.
[52] D. Gebrezgi, "Proximate composition of complementary food prepared from maize (Zea mays), soybean (Glycine max) and Moringa leaves in Tigray, Ethiopia," Cogent Food \& Agriculture, vol. 5, no. 1, p. 1627779, 2019.

[53] L. Rooney, "Sorghum and millets," in Cereal grain quality, pp. 153-177, Springer, 1996.

[54] B. S. S. Jean Mayer, "The effects of food processing on nutritional values," Nutrition Reviews, vol. 33, no. 4, pp. 123-126, 1975.

[55] B. Hocking and F. Matsumura, "Bee brood as food," Bee World, vol. 41, no. 5, pp. 113-120, 1960.

[56] R. Krell, Value-Added Products from Beekeeping, Food \& Agriculture Org, 1996.

[57] C. A. Chapman, L. J. Chapman, K. D. Rode, E. M. Hauck, and L. R. McDowell, "Variation in the nutritional value of primate foods: among trees, time periods, and areas," International Journal of Primatology, vol. 24, no. 2, pp. 317-333, 2003.

[58] L. Kouřimská and A. Adámková, "Nutritional and sensory quality of edible insects," NFS journal, vol. 4, pp. 22-26, 2016.

[59] P. J. Fellows, Food Processing Technology, P. J. Fellows, Ed., Woodhead publishing, fourth edition, 2017.

[60] I. Elmadfa and A. L. Meyer, "Importance of food composition data to nutrition and public health," European Journal of Clinical Nutrition, vol. 64, no. S3, pp. S4-S7, 2010.

[61] A. C. Codex, Corn Soya Sugar Blend for Young Children and Adults. Food and Agriculture Organization of the United Nations. [Rome], 2010.

[62] K. G. Dewey and K. Brown, "Update on technical issues concerning complementary feeding of young children in developing countries and implications for intervention programs," Food nutrition bulletin, vol. 24, no. 1, pp. 5-28, 2003.

[63] FAO/WHO, Vitamin and Mineral Requirements in Human Nutrition, vol. 57, World Health Organization, Geneva, 2002.

[64] WFP, World Food Policy WFP, WFP Specification for Fortified Blended Food, 2013, https://documents.wfp.org/ stellent/groups/public/documents/manual_guide_proced/ wfp251160.

[65] K. Eichler, S. Wieser, I. Rüthemann, and U. Brügger, "Effects of micronutrient fortified milk and cereal food for infants and children: a systematic review," BMC Public Health, vol. 12, no. 1, p. 506, 2012.

[66] A. A. Leaf, "Vitamins for babies and young children," Archives of Disease in Childhood, vol. 92, no. 2, pp. 160164, 2006.

[67] National Academies of Sciences, Engineering, and Medicine; Health and Medicine Division; Food and Nutrition Board; Committee to Review the Dietary Reference Intakes for Sodium and Potassium, Dietary Reference Intakes for Sodium and Potassium, M. Oria, M. Harrison, and V. A. Stallings, Eds., National Academies Press (US), Washington (DC), 2019.

[68] N. Roos, J. C. Sørensen, H. Sørensen et al., "Screening for anti-nutritional compounds in complementary foods and food aid products for infants and young children," Maternal \& child nutrition, vol. 9, pp. 47-71, 2013.

[69] F. K. Amagloh, A. Hardacre, A. N. Mutukumira, J. L. Weber, L. Brough, and J. Coad, "Sweet potato-based complementary food for infants in low-income countries," Food and Nutrition Bulletin, vol. 33, no. 1, pp. 3-10, 2012. 
[70] M. Ogunkoya, F. Abulude, and A. Oni, "Determination of anatomical, proximate, minerals, oxalate, tannin and phytate compositions of Cuban Boa (Epicrates anquifer)," Journal of Environmental Agricultural and Food Chemistry, vol. 5, no. 1, pp. 1161-1166, 2006.

[71] L. Hallberg, M. Brune, and L. Rossander, "Iron absorption in man: ascorbic acid and dose-dependent inhibition by phytate," The American Journal of Clinical Nutrition, vol. 49, no. 1, pp. 140-144, 1989.

[72] A.-S. Sandberg, H. Andersson, N.-G. Carlsson, and B. Sandström, "Degradation products of bran phytate formed during digestion in the human small intestine: effect of extrusion cooking on digestibility," The Journal of Nutrition, vol. 117, no. 12, pp. 2061-2065, 1987.

[73] G. S. Bindra, R. S. Gibson, and L. U. J. N. R. Thompson, "[Phytate][calcium]/[zinc] ratios in Asian immigrant lactoovo vegetarian diets and their relationship to zinc nutriture," vol. 6 , no. 5, pp. $475-483,1986$.

[74] E. R. Morris and R. Ellis, "Usefulness of the dietary phytic acid/zinc molar ratio as an index of zinc bioavailability to rats and humans," Biological Trace Element Research, vol. 19, no. 1-2, pp. 107-117, 1989.

[75] J. C. Anuonye, A. A. Jigam, and G. M. Ndaceko, "Effects of extrusion-cooking on the nutrient and anti-nutrient composition of pigeon pea and unripe plantain blends," Journal of Applied Pharmaceutical Science, vol. 2, no. 5, pp. 158-162, 2012.

[76] S. K. Sathe and M. Venkatachalam, Influence of Processing Technologies on Phytate and Its Removal, CRC Press, Washington, DC, 2002.

[77] S. M. Al Hasan, M. Hassan, S. Saha, M. Islam, M. Billah, and S. J. B. N. Islam, "Dietary phytate intake inhibits the bioavailability of iron and calcium in the diets of pregnant women in rural Bangladesh: a cross-sectional study," BMC Nutrition, vol. 2, no. 1, p. 24, 2016.

[78] V. Ramakrishna, P. J. Rani, and P. R. Rao, “Anti-nutritional factors during germination in Indian bean (Dolichos lablab L.) seeds," World Journal of Dairy Food Sciences, vol. 1, no. 1, pp. 6-11, 2006.

[79] ICMSF, Microorganisms in Foods. A Publication of the International Commission on Microbiological Specifications for Foods (ICMSF) of the International Association of Microbiological Societies, University of Toronto Press, 1978, http:// worldcat.org/z-wcorg/.

[80] A. K. Amegovu, P. Ogwok, S. Ochola, P. Yiga, J. H. Musalima, and E. Mutenyo, "Formulation of sorghum-peanut blend using linear programming for treatment of moderate acute malnutrition in Uganda," Journal of Food Chemistry and Nutrition, vol. 1, no. 2, pp. 67-77, 2013.

[81] C. Obi and N. Nwozor, "Bacteriological analyses of weaning foods consumed in Umuariaga community, Ikwuano L.G.A. Abia state," Research Journal of Applied Sciences, vol. 7, no. 4, pp. 208-211, 2012.

[82] R. A. Suleiman, K. A. Rosentrater, and C. J. Bern, "Effects of deterioration parameters on storage of maize," American Society of Agricultural and Biological Engineers, vol. 1, 2013.

[83] R. Srivalli, B. A. Kumari, K. U. Maheswari, W. J. Suneetha, and B. N. Prabhakar, "Shelf life studies of tomato powder incorporated cold extrudates," International Journal of Current Microbiology and Applied Sciences, vol. 6, no. 4, pp. 1569-1575, 2017.
[84] F. Cetinkaya, R. Cibik, G. E. Soyutemiz, C. Ozakin, R. Kayali, and B. Levent, "Shigella and Salmonella contamination in various foodstuffs in Turkey," Food Control, vol. 19, no. 11, pp. 1059-1063, 2008.

[85] D. Muleta and M. Ashenafi, "Salmonella, Shigella and growth potential of other food-borne pathogens in Ethiopian street vended foods," East African Medical Journal, vol. 78, no. 11, pp. 576-580, 2001.

[86] T. Verma, Validation of extrusion processing for the safety of low-moisture foods, 2017, https://digitalcommons.unl.edu/ foodscidiss $/ 83 /$.

[87] E. Gungor and N. Gokoglu, "Determination of microbial contamination sources at a frankfurter sausage processing line," Türk veterinerlik ve hayvancilik dergisi $=$ Turkish journal of veterinary \& animal sciences, vol. 34 , no. 1, pp. 5360, 2010.

[88] O. W. Lau and S. Wong, "Contamination in food from packaging material," Journal of chromatography A, vol. 882, no. 12, pp. 255-270, 2000.

[89] M. Tshipamba, N. Lubanza, M. Adetunji, and M. Mwanza, "Evaluation of the effect of hygiene practices and attitudes on the microbial quality of street vended meats sold in Johannesburg, South-Africa," Journal of Food: Microbiology, Safety \& Hygiene, vol. 3, no. 137, pp. 2476-3059, 2018.

[90] F. I. Uzma Altaf, S. Z. Hussain, S. A. Ishrat, and Q. Ayaz, "Shelf life studies of the optimized extruded product developed by severe extrusion processing," IJCS, vol. 7, no. 5, pp. 667-670, 2019.

[91] T. M. Valerie, P. B. Mislivec, H. A. Koch, R. Bandler, and United States Food Drug Administration, Bacteriological Analytical Manual (BAM) Chapter 18, AOAC International, Gaithersburg, Md., 2001.

[92] C. J. Stannard, S. B. Petitt, and F. A. Skinner, Eds., Rapid Microbiological Methods for Foods, Beverages, and Pharmaceuticals, Brookline Village, Mass.: Blackwell Scientific Publications ; Publishers' Business Services [distributor], Oxford; Boston, 1989.

[93] J. F. Spencer and A. L. Spencerde, Eds., Food Microbiology Protocols, vol. 14, Springer Science \& Business Media, 2001.

[94] H. Stone, "Example food: what are its sensory properties and why is that important?," Npj Science of Food, vol. 2, no. 1, 2018.

[95] L. Svensson, Design and performance of small scale sensory consumer tests, (Masters independent project/degree project in food science - Master's thesis), Swedish University of Agricultural Sciences, Uppsala, 2012, http://stud.epsilon.slu .se/.

[96] H. S. Muhimbula, A. Issa-Zacharia, and J. Kinabo, "Formulation and sensory evaluation of complementary foods from local, cheap and readily available cereals and legumes in Iringa, Tanzania," African Journal of Food Science, vol. 5, no. 1, pp. 26-31, 2011.

[97] C. A. Ikpeme-Emmanuel, J. Okoi, and N. C. Osuchukwu, "Functional, anti-nutritional and sensory acceptability of taro and soybean based weaning food," African Journal of Food Science, vol. 3, no. 11, pp. 372-377, 2009.

[98] J. G. Lavin and H. T. Lawless, "Effects of color and odor on judgments of sweetness among children and adults," Food Quality and Preference, vol. 9, no. 4, pp. 283-289, 1998. 
[99] J.-X. Guinard, "Sensory and consumer testing with children," Trends in Food Science \& Technology, vol. 11, no. 8, pp. 273283, 2000.

[100] J. F. Haro-Vicente, M. J. Bernal-Cava, A. Lopez-Fernandez, G. Ros-Berruezo, S. Bodenstab, and L. M. J. N. Sanchez-Siles, "Sensory acceptability of infant cereals with whole grain in infants and young children," Nutrients, vol. 9, no. 1, p. 65, 2017.

[101] J. Madrelle, C. Lange, I. Boutrolle et al., "Development of a new in-home testing method to assess infant food liking," Appetite, vol. 113, pp. 274-283, 2017. 